https://doi.org/10.18485/kud_kiaz.2019.ch7

Шукюфа Джабарова

доцент кафедры Философии и общественных наук АУя, Баку, Азербайджан, cshb@mail.ru

\title{
РЕЛИГИОЗНАЯ ТОЛЕРАНТНОСТЬ И МНОГОКОНФЕССИОНАЛЬНОСТЬ В СОВРЕМЕННОМ АЗЕРБАЙДЖАНЕ
}

\begin{abstract}
SUMMARY
The article of Sh. Dzhabarova « Religious tolerance and multiconfessional in modern Azerbaijan» says that the unique geographical position made Azerbaijan an attractive place for many nationalities and denominations. Historically, the following religions have changed in our country: Zoroastrianism, Judaism, Christianity, Islam. In modern Azerbaijan, there are three large Jewish communities: Mountain Jews, Ashkenazi Jews and Georgian Jews. Christianity is represented in Azerbaijan by three main branches: Orthodoxy, Catholicism and Protestantism. The bulk of the population of the republic professes Islam. The article concludes that modern Azerbaijan is a secular, multicultural and multi-religious society. Representatives of various religions and ethnic groups live in peace and harmony. This is the result of the policy pursued by the Azerbaijani state.
\end{abstract}

Key words: Azerbaijan, tolerance, multiculturalism, religions in Azerbaijan.

Азербайджан в течение многих столетий является многоконфессиональной страной, в которой мирно уживаются и сосуществуют различные религии. Само географическое положение Азербайджана, который находится на стыке торговых путей между Западом и Востоком, благоприятные климатические условия и богатые природные 
ресурсы делали Азербайджан привлекательным местом для многих людей других национальностей и конфессий.

Традиционно считается, что самой ранней религиозной системой в Азербайджане являлся Зороастризм, возникший в первой половине I тыс. до н.э. Многие исследователи полают, что Зороастризм возник на территории Азербайджана и получил широкое распространение на Ближнем Востоке и Индии. В пригороде Баку, в поселке Сураханы до сих пор сохранился Храм Огнепоклонников, который является одним из символов Баку. По сегодняшний день последователи этой религии из Индии и Ирана совершают паломничество к этому храму.

Первой монотеистической религией распространенной в Азербайджане был иудаизм. Как подчеркивает М.Беккер «появление еврейских поселенцев на земле Азербайджана тесно связано с взятием Иерусалима вавилонским царем Навуходоносором II, который в 586 году до н. э. захватил столицу древнего Иудейского царства, разрушил город и храм и увел в рабство около 10\% населения» [3, 269].

В современном Азербайджане существуют три большие еврейские общины: горские евреи, евреи-ашкенази и грузинские евреи. В Азербайджане на сегодняшний день проживает около 26 тысяч евреев [3]. В республике действуют 6 синагог, еврейские культурные центры и религиозные организации. На территории Кубинского района уже несколько веков компактно живет община горских евреев (около 4 тыс. чел) - поселок Красная слобода. В данный момент в поселке действуют две восстановленные синагоги. Синагога, открытая 9 марта 2003 года в Баку, считается одной из самых больших в Европе. В двух ведущих вузах Азербайджана - Бакинском Государственном Университете и Азербайджанском Университете Языков открыто отделение израилеведения и изучения иврита.

Евреи в Азербайджане всегда чувствовали себя в безопасности. Американский журнал Тіме опубликовал статью старшего раввина Синайского храма Дэвида Волпа под на- 
званием "Азербайджан - оазис толерантности на Ближнем Востоке", в которой глава известной синагоги Лос-Анджелеса пишет о своих впечатлениях после визита делегации в составе 50 членов конгрегации в Азербайджан в ноябре 2016 года. В статье Д.Волп отмечает, что многие синагоги в различных странах не общедоступны в любое время суток. "Даже в моей синагоге в Лос-Анджелесе работники охраны здания проверяют багажники прибывающих в синагогу машин", - пишет раввин. Однако в одной мусульманской стране, евреи могут свободно заходить в синагоги без какой-либо проверки в целях безопасности, и это Азербайджан. Он пишет, что именно поэтому Азербайджан является ярким отличием от остального мира [1].

История христианства в Азербайджане насчитывает более 2 тысяч лет. Появление христианства на территории современного Азербайджана неразрывно связано с именем одного из двенадцати учеников Иисуса Христа апостола Варфоломея. Иеромонах Алексий (Никоноров) в своей диссертации «История христианства в кавказской Албании» подчеркивает, что «именно он первым огласил евангельской проповедью эту древнюю землю. Церковное предание свидетельствует о том, что святой Варфоломей пострадал и принял смерть за Христа в г. Баку в 71 г. н.э. В центре города у подножья Девичьей башни находится памятное место, где была пролита кровь апостола, и это место свято почитается христианами на протяжении двух тысячелетий. До 1936 года место это было отмечено часовней, памятная доска на которой сообщала об этом. В I тысячелетии христианство широко распространилось в Кавказской Албании, на территории которой находится современный Азербайджан, и в 4 веке здесь была организована самостоятельная Албанская Церковь, которая просуществовала вплоть до начала 19 века» [2].

Сегодня христианство представлено в Азербайджане тремя основными ветвями: Православие, Католицизм и Протестантизм. 
Православие в Азербайджане - вторая по численности конфессия после ислама. Православных в Азербайджане приблизительно 209,7 тыс. человек. Территория Азербайджана находится в юрисдикции Бакинско-Азербайджанской Епархии Русской православной церкви. Первый православный храм в Баку появляется в 1815 году. 1905 году образована Бакинская епархия Русской Православной церкви. В советское время власти репрессировали священнослужителей Бакинской епархии, но уже в 1944 году были открыты 2 храма. В 1998 году была образована Бакинско - Прикаспийская епархия Русской православной церкви. На 2016 год в стране действует 5 христианских православных храмов и 2 молельных дома.

Говоря о православии в Баку нельзя не вспомнить о православном храме Александра Невского. Этот храм был крупнейшим во всем Закавказье и являлся рукотворным символом христианства, он был виден со всех сторон Баку. Российский император Александр III специально приехал в Баку 8 октября 1888 года и лично участвовал в символической закладке фундамента будущего храма. Через 10 лет, в 1898 году, когда строительство было окончено, на открытии церкви принимал участие уже сын Александра III - Николай II. В память о таком знаменательном событии азербайджанский меценат 3.Тагиев пожертвовал 10 тысяч рублей на нужды православных церковно-приходских школ и на начальные училища Бакинского уезда. На строительство собора были выделены не малые средства, так как Александр III поставил условие, чтобы собор был исключительным по роскоши и красоте. Когда проект был почти готов, выяснилось, что средств отпущенных царем, маловато. Начался сбор пожертвований. Показательным фактом является то, что из двухсот тысяч рублей, собранных в Баку, сто пятьдесят тысяч рублей пожертвовали мусульмане [7].

К великому сожалению в 30-40-е годы XX века по решению коммунистов были снесены и перенаправлены на другие цели многие церкви, мечети, синагоги по всей 
стране. Эта участь не миновала и одно из красивейших православных храмов в Закавказье. Она была взорвана.

Католичество в Азербайджане начало распространятся в начале 14 века. Период расцвета католических общин приходится на XVII век. В это время в Ширване, Баку, Шамахе, Нахчиване, Гяндже, Тебризе появляются общины кармелитов, доминиканцев, капуцинов, августинцев, иезуитов. У них были свои монастыри, церкви и учебные заведения. Монахи занимались в основном просветительской деятельностью, проповедью Евангелия и медициной [9].

Новейшая история Католической Церкви связана с периодом независимости Азербайджана. Восстановление католической общины в нашей стране началось в 1992 году. 2 апреля 1999 года католическая община Азербайджана официально была зарегистрирована.

В мае 2002 года в жизни Католической Церкви Азербайджана происходит исключительное событие. Азербайджан посещает с официальным визитом Папа Римский Иоанн Павел II. Папа совершил богослужение - Святую Мессу - во Дворце Ручных Игр, при участии нескольких тысяч людей. Очень сложно переоценить значение этого визита для жизни Католической Церкви Азербайджана. Президент Гейдар Алиев подарил католической общине участок земли для строительства нового католического храма, вместо уничтоженного большевиками. Строящийся католический храм было решено посвятить Непорочному Зачатию Девы Марии в память об уничтоженной большевиками церкви. В апреле 2007 года апостольский нунций Южного Кавказа архиепископ К.Гуджеротти освятил храм, и в нём впервые состоялась Божественная Литургия (Святая Месса). С этого дня основные богослужения стали совершаться в новом храме.

07 июля 2011 года Азербайджан и Ватикан подписали документ о правовом статусе Католической церкви в республике. «Азербайджан еще раз подтвердил свою толерантность. Весь мир знает об этом. Уверен, что этот 
документ, вызвавший положительный резонанс в мире, останется в памяти как историческое событие» [6], - заявил апостольский нунций в Баку К. Гуджеротти на церемонии получения им удостоверения об официальной регистрации католической общины. К.Гуджеротти указал на то, что прежде Ватикан ни с одной страной не подписывал такого соглашения.

2 октября 2016 года состоялся визит Папы Римского Франциска в Азербайджан. Папа Римский Франциск поблагодарил представителей религиозных общин за гостеприимство. Подчеркнув, что в Азербайджане сохраняются религиозные ценности, Папа Римский отметил, что мирные общества появляются в результате сотрудничества. «Наша нынешняя встреча является продолжением многих встреч, проведенных в Баку для поощрения диалога и мультикультурализма. Открывая двери перед единением и интеграцией, вы словно распахиваете двери в душу каждого человека. Открываете двери надежды для них. Уверен, что Азербайджан, являющийся воротами между Востоком и Западом, всегда развивал в себе культуру открытости, являющуюся основой с точки зрения построения мира для людей и прочного фундамента для блестящего будущего человечества» [4] , - сказал он.

Распространение протестантизма. Первой протестантской сектой, распространенной в Азербайджане, стало лютеранство. Появление лютеранства в нашей стране связано с переселением в первой половине XIX века немцев и поляков на Южный Кавказ. Немецкой общиной была основана лютеранская церковь в Азербайджане. В 1854 г. была основана кирха в Еленендорфе (г.Гейгель), а в 1909 г. — кирха в Анненфельде (г.Шамкир). В 1899 г. была открыта лютеранская кирха в городе Баку. Лютеранские церкви были воздвигнуты по проектам немецких архитекторов А.Эйхлера и Ф.Лемкуля.

В 2017 году исполняется 200 лет с момента переселения немцев и создания немецких поселений на Юж- 
ном Кавказе, в частности, на территории Азербайджана. В связи с этой датой в стране будут проведены различные мероприятия. По данным The Pew Forum on Religion \& Public Life в настоящее время в Азербайджане проживают до 20 тыс. протестантов [8].

Большая часть населения Азербайджана исповедует Ислам. Известный историк Ахмад аль-Балазури в сочинении «Книга завоеваний государств» писал, что уже в период правления халифа Али ибн Абу-Талиба (656 - 661) большинство населения Азербайджана приняло ислам [5, 73-74].

Построенная в 743 году Джума мечеть Шамахы - одна из самых древних и больших мечетей не только Азербайджана, но и всего Южного Кавказа. Согласно некоторым источникам, именно в этой мечети хазарский хаган принял ислам.

Сегодня более 90\% населения страны - мусульмане. Около 85\% мусульман Азербайджана исповедуют ислам шиитского толка, а 15 \% - мусульмане-сунниты.

Современный Азербайджан - светское, мультикультурное и многоконфессиональное общество. Представители различных религий и этносов живут в мире и согласии. Этому способствует и политика, проводимая Азербайджанским государством. Президент Азербайджана Ильхам Алиев каждый год обращается к мусульманам, христианам и евреям по случаю религиозных праздников и знаменательных дней, встречается с главами религиозных общин. Всем зарегистрированным религиозным конфессиям оказывается материальная поддержка из личного фонда Президента. В настоящее время продолжаются последовательные меры по реставрации исторических храмов, мечетей, церквей, синагог. Сегодня есть и те, кто считает пропаганду и распространение традиций толерантности незначимым. Но толерантность продукт не только правового государства, а культурно и духовно развитого общества. Именно в этом и заключается отличительная особенность сегодняшнего Азербайджана и азербайджанцев. 


\section{Список использованной литературы}

Azerbaijan Is an Oasis of Tolerance in the Middle East // http://time. com/ 4099548/ azerbaijan-is-an-oasis-of-tolerance-in-the-middle-east/

Алексий (Никоноров) История христианства в кавказской Албании. Диссертация на соискание ученой степени кандидата богословия. Троице-Сергиева Лавра 2004 г. http://baku.eparhia.ru/history/ albania/

М.Беккер. Евреи в Азербайджане: история и перспективы // Центральная Азия и Кавказ, 2000, № 2.

Визит Папы Римского Франциска в Азербайджан // http:// news.day.az/politics/826893.htm

Источники по истории Азербайджана (на азерб.языке), Баку, 1989.

Католическая община Азербайджанаполучилагосрегистрацию // http://interfax-religion.ru/cis.php/print.php?act=news\&div=41409

Сулейманов М. Дни минувшие (Исторические очерки) // http:// ebooks.azlibnet.az/book/GjkqXSRB.pdf

Table: Christian Population in Numbers by Country

http://www.pewforum.org/2011/12/19/table-christian-population-in-numbers-by-country/

Церковь в Азербайджане // http://www.catholic.az/ru

\section{РЕЗЮМЕ}

В статье Ш.Джабаровой говорится, что уникальное географическое положение делало Азербайджан привлекательным местом для многих национальностей и конфессий. Исторически на территории нашей страны сменялись следующие религии: Зороастризм, Иудаизм, Христианство, Ислам. В современном Азербайджане существуют три большие еврейские общины: горские евреи, евреи-ашкенази и грузинские евреи. Христианство представлено в Азербайджане тремя основными ветвями: Православие, Католицизм и Протестантизм. Основная часть населения республики исповедует Ислам. В заключении статьи подчеркивается, что современный Азербайджан - светское, мультикультурное и многоконфессиональное общество. Представители различных религий и этносов живут в мире и согласии. Этому способствует и политика, проводимая Азербайджанским государством.

Ключевые слова: Азербайджан, толерантность, мультикультурализм, религии в Азербайджане. 